\title{
2,4-Dichlorophenoxyacetic acid degradation in methanogenic mixed cultures obtained from Brazilian Amazonian soil samples
}

\author{
Gunther Brucha • Andrea Aldas-Vargas - Zacchariah Ross • Peng Peng • \\ Siavash Atashgahi · Hauke Smidt • Alette Langenhoff • Nora B. Sutton
}

Received: 3 June 2020/Accepted: 31 March 2021 / Published online: 20 April 2021

(C) The Author(s) 2021

\begin{abstract}
Dichlorophenoxyacetic acid (2,4-D) is the third most applied pesticide in Brazil to control broadleaf weeds in crop cultivation and pastures. Due to 2,4-D's high mobility and long half-life under anoxic conditions, this herbicide has high probability for groundwater contamination. Bioremediation is an attractive solution for 2,4-D contaminated anoxic environments, but there is limited understanding of anaerobic 2,4-D biodegradation. In this study, methanogenic enrichment cultures were obtained from Amazonian top soil $(0-40 \mathrm{~cm})$ and deep soil (50 $80 \mathrm{~cm}$ below ground) that biotransform 2,4-D $(5 \mu \mathrm{M})$ to 4-chlorophenol and phenol. When these cultures were transferred $(10 \% \mathrm{v} / \mathrm{v})$ to fresh medium containing $40 \mu \mathrm{M}$ or $160 \mu \mathrm{M} 2,4-\mathrm{D}$, the rate of $2,4-\mathrm{D}$
\end{abstract}

Supplementary Information The online version contains supplementary material available at https://doi.org/10.1007/ s10532-021-09940-3.

G. Brucha - A. Aldas-Vargas - Z. Ross ·

A. Langenhoff · N. B. Sutton ( $\square)$

Environmental Technology, Wageningen University \&

Research, PO BOX 17, 6700 EV Wageningen, The

Netherlands

e-mail: Nora.Sutton@wur.nl

G. Brucha

Institute of Science and Technology, Universidade

Federal de Alfenas, Alfenas, Brazil

P. Peng $\cdot$ S. Atashgahi $\cdot$ H. Smidt

Laboratory of Microbiology, Wageningen University \&

Research, Wageningen, The Netherlands degradation decreased, and biotransformation did not proceed beyond 4-chlorophenol and 2,4-dichlorophenol in the top and deep soil cultures, respectively. $16 \mathrm{~S}$ rRNA gene sequencing and qPCR of a selection of microbes revealed no significant enrichment of known organohalide-respiring bacteria. Furthermore, a member of the genus Cryptanaerobacter was identified as possibly responsible for phenol conversion to benzoate in the top soil inoculated culture. Overall, these results demonstrate the effect of 2,4-D concentration on biodegradation and microbial community composition, which are both important factors when developing pesticide bioremediation technologies.

Keywords Pesticide $\cdot$ 2,4-Dichlorophenoxyacetic acid $\cdot$ Methanogenic $\cdot$ Biodegradation $\cdot$ Soil . Microbial diversity

\section{Introduction}

The Brazilian agriculture sector has undergone enormous growth in recent decades, with the country now becoming one of the world's largest supplier of soy, coffee, sugar cane and corn, among other commodities (FAO 2015). However, this rapid growth has relied heavily on the use of pesticides. In 2008, Brazil became the world's largest market for pesticide import, and in 2015, 899 million litres of pesticides 
were used (Piganati et al. 2017). Pesticide use is regulated under a Federal law in Brazil since 1989 (ANVISA 2011), however, crop and freshwater monitoring has shown pesticide concentrations regularly exceed allowed levels and water quality criteria (Jardim and Caldas 2012; Albuquerque et al. 2016; Barbosa et al. 2015).

2,4-Dichlorophenoxyacetic acid (2,4-D), an auxin hormone mimic, is the third most widely applied pesticide in Brazil (Barbosa et al. 2015), used to control broadleaf weeds in cereal and sugarcane cultivation as well as pastures. For systemic hormonal action, 2,4-D is classified toxicologically in Brazil as class I (highly toxic) (ANVISA 2016) and as class III for environmental hazards (product dangerous to the environment) (Rebelo et al. 2010). Although 2,4-D was reported to have a relatively short aerobic soil half-life of 6.2 days (EPA 2005), its degradation rate is strongly influenced by several factors such as $\mathrm{pH}$, temperature and moisture (Sandmann et al. 1988). Combined with 2,4-D's high terrestrial mobility (EPA 2005), this enhances the potential for percolation through the soil and into groundwater systems. Once present in anoxic environments, including saturated agricultural land and aquifers, 2,4-D is considered 'persistent' to 'highly persistent' with a half-life of 41-333 days (EPA 2005). Therefore, the stability and mobility of 2,4-D within anoxic environmental systems causes concern for the transport to and contamination of offsite locations such as surface water and drinking water resources. Hence, the development of reliable and affordable technologies to remediate contaminated anoxic subsurface environments is needed to minimize the human health and environmental risks associated with 2,4-D.

Bioremediation has been identified as a costeffective and environmental friendly technology for the treatment of polluted environments (Azubuike et al. 2016). In addition, there are a growing number of reports on anaerobic microbial transformation of 2,4D under methanogenic (Gibson and Sulfita 1986; Zipper et al. 1999; Berestovskya et al. 2000; Yang et al. 2017), sulfate-reducing (Boyle et al. 1999; Roblez-Gonzalez et al. 2006) and iron-reducing conditions (Wu et al. 2009). Different microbes have been associated with the removal of the acetic acid and chloride groups from 2,4-D (Boyle et al. 1999), such as bacteria belonging to the genera Alcaligenes, Bulkoderia, Rhodoferax, Variovorax, Cupriavidus,
Achromobacter, Comamonas, Holomonas and Pseudomonas (Streber et al. 1987; Fulthorpe et al. 1995; Dom and Pamberton 1981; Zharikova et al. 2018). Although little is known about the enzymatic processes involved in anaerobic 2,4-D biodegradation, the identification of several metabolic intermediates has allowed inferring different degradation pathways (Fig. 1). The removal of chloride substitutes from 2,4-D and its metabolites were proposed to occur by reductive dechlorination, where 2,4-D acts as a terminal electron acceptor (Yang et al. 2017; Wang et al. 2009; Roblez-Gonzalez et al. 2006).

Reductive dechlorination can proceed through either co-metabolic processes or an energy-conserving metabolic mechanism known as organohalide respiration (OHR) (Smidt and de Vos 2004). The latter is mediated by organohalide-respiring bacteria (OHRB) that belong to distinct microbial groups in the phyla Chloroflexi, Firmicutes and Proteobacteria. Members of the genus Desulfitobacterium (Firmicutes) and proteobacterial genera Geobacter and Sulfurospirillum belong to the facultative OHRB with diverse metabolic capabilities with respect to the use of a variety of electron donors and acceptors including but not restricted to halogenated organic compounds (organohalides) (Futagami and Furukawa 2016). In contrast, members of Dehalococcoides (Chloroflexi) and Dehalobacter (Firmicutes) are obligate OHRB that only use organohalides as electron acceptors and hydrogen as an electron donor (Atashgahi et al. 2016). Therefore, 2,4-D and its chlorinated intermediates are likely reductively dechlorinated through $\mathrm{OHR}$ by OHRB. One such organism, the ferric iron-reducing Comamonas koreensis CY01, can directly reduce 2,4$\mathrm{D}$, although intermediates were not identified (Wang et al. 2009). Ha (2018) showed that Thauera sp. DKT could use 2,4-D and its intermediates 2,4-dichlorophenol (2,4-DCP), 4-chlorophenol (4-CP), 2-chlorophenol (2-CP) and phenol as a carbon and energy source under denitrifying conditions. Members of the genera Dehalobacter and Desulfitobacterium can respire, or are associated, with the reduction of 2,4-D and its intermediates 2,4-DCP, 4-CP and 2-CP (Wang et al. 2014; Li et al. 2013; Madsen and Licht et al. 1992; Thibodeau et al. 2004). Although co-metabolic reductive dechlorination of chlorinated aromatics was previously reported to be rare (Holliger et al. 2004), however recent research has also reported co-metabolic degradation of chlorinated compounds (Becker 
<smiles>O=C(O)COc1ccc(Cl)cc1Cl</smiles>

2,4-D

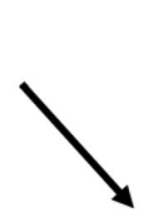<smiles>O=C(O)COc1ccc(Cl)cc1</smiles>

Fig. 1 Biotransformation of 2,4-dichlorophenoxyacetic acid under anoxic conditions numbers below the compounds indicate the used references that detected those intermediates during the anaerobic microbial transformation of 2,4-D. (i) Gibson and Suflita (1986); (ii) Bryant et al. (1992); (iii) Boyle et al. (1999); (iv) Zipper et al. (1999); (v) Berestovskya et al. (2000); (vi)

and Freedman 2014, Peng et al. 2020). Dehalococcoides mccartyi strain CBDB1 has been shown to cometabolically dechlorinate 2,4-DCP to 4-CP (Adrian et al. 2007).

The aim of this investigation was to obtain enrichment cultures from Amazonian top $(0-40 \mathrm{~cm})$ and deep $(50-80 \mathrm{~cm})$ soil samples capable of 2,4-D transformation under methanogenic conditions. The influence of the soil sample depth and 2,4-D concentrations on the 2,4-D degradation capacity and the microbial community composition were monitored by metabolite analyses as well as Illumina MiSeq sequencing of PCR-amplified partial 16S rRNA genes and quantitative PCR (qPCR). This work contributes to further understanding of microbial 2,4-D degradation under methanogenic conditions and the involved microbial community, important insights for the development of pesticide bioremediation technologies.
Roblez-Gonzalez et al. (2006); (vii) Wu et al. (2009); (viii) Yang et al. (2017). Abbreviations used: 2,4-D = 2,4-dichlorophenoxyacetic acid; 2,4-DCP $=2,4$-dichlorophenol; $4-\mathrm{C}=4$ chlorophenoxyacetic acid; 4-CP = 4-chlorophenol; 2-CP = 2chlorophenol. Image produced on Chemsketch (ACD)

\section{Materials and methods}

Soil sampling

Soil was sampled from Fazenda Nova Vida $\left(10^{\circ} 10^{\prime} 58,11^{\prime \prime}\right.$ south, $62^{\circ} 49^{\prime} 20,74^{\prime \prime}$ west), in Rondônia, Brazil. This farm has applied 2,4-D to control broadleaf weeds on its pasture for decades (Morais et al. 1996), and is a study location to compare physicochemical and microbiological aspects of the forest and pasture soil (Neill et al. 1995; Rodrigues et al. 2013). Soil samples were obtained at 0-40 cm (top soil) and 50-80 cm deep (deep soil) in August and October 2015, respectively, and were stored at $4{ }^{\circ} \mathrm{C}$ for 2 months until starting the microcosms.

\section{Microcosm setup}

The 1st generation microcosms were set up with $60 \mathrm{~g}$ soil and $300 \mathrm{ml}$ anaerobic medium (in $500 \mathrm{ml}$ flasks with butyl rubber stoppers). The basal medium was prepared according to Zinder et al. (1984) with a $\mathrm{N}_{2}: \mathrm{CO}_{2}$ (70:30) atmosphere and amended with $10 \mathrm{ml}$ 
$\mathrm{L}^{-1}$ of vitamin (Touzel and Albagnac 1983), buffered with $0.1 \%$ of $\mathrm{NaHCO}_{3}\left(100 \mathrm{~g} \mathrm{~L}^{-1}\right)$ and reduced with $0.05 \%$ of $\mathrm{Na}_{2} \mathrm{~S} .9 \mathrm{H}_{2} \mathrm{O}$. Medium was supplemented with $1 \mathrm{mM}$ acetate and $1 \mathrm{mM}$ lactate as carbon source, and $5 \mu \mathrm{M}$ 2,4-D as electron acceptor. The media was buffered at a $\mathrm{pH}$ of 7.0. Two sets of microcosms were prepared in triplicate, one with top soil, and another with deep soil. The microcosms were incubated in the dark at $30{ }^{\circ} \mathrm{C}$, shaking at $150 \mathrm{rpm}$ for 210 days with top soil material, and 90 days with deep soil material. During this period, $1 \mathrm{mM}$ acetate and lactate were readded at days 57 and 175 to top soil and at day 35 to deep soil microcosms.

These microcosms were used as inocula for the 2nd generation microcosms (2nd gen $5 \mu \mathrm{M}$ microcosm), that were performed in triplicate. $40 \%$ inoculum $(\mathrm{v} / \mathrm{v})$ from the 1 st generation microcosms was transferred into $120 \mathrm{ml}$ bottles containing $50 \mathrm{ml}$ of anoxic mineral medium prepared according to Holliger et al. (1998), amended with $10 \mathrm{mM}$ acetate and $10 \mathrm{mM}$ lactate, $5 \mu \mathrm{M}$ 2,4-D, $5 \mu \mathrm{M}$ 2-(4-Chloro-2 methylphenoxy) propionic acid (MCPP), and $5 \mu \mathrm{M}$ 2,6-dichlorobenzamide (BAM) (Fig. 2). Abiotic controls were prepared similarly, with electron donors, pesticides and further addition of $2 \mathrm{mM} \mathrm{NaN}_{3}$ and $1 \mathrm{mM} \mathrm{HgCl} 2$. Biotic controls were also prepared similarly to biotic and abiotic microcosms, including electron donors, but without pesticides. The microcosms were incubated in the dark at $30{ }^{\circ} \mathrm{C}$, and shaken at $150 \mathrm{rpm}$ for 206 days. $10 \mathrm{mM}$ acetate and $10 \mathrm{mM}$ lactate were re-spiked on days 13, 39, 54, 67, 94, 110, $117,125,137,151,160,171$ and 177 to all bottles, except to the abiotic and biotic controls. Media was refreshed to prevent salt accumulation from the electron donor (potassium acetate and sodium lactate) by adding mineral medium $(20 \mathrm{ml})$, pesticides $(5 \mu \mathrm{M})$, acetate $(10 \mathrm{mM})$ and lactate $(10 \mathrm{mM})$ on day 94 . Moreover, $5 \mu \mathrm{M}$ of 2,4-D was supplied to the microcosms with top soil on days 94 and 151, and on day 94 to microcosms with deep soil, as 2,4-D depletion was observed in these bottles (Fig. 2).

To study the impact of higher concentrations of pesticides, 3rd generation microcosms (3rd gen) were prepared. 3rd gen $40 \mu \mathrm{M}$ microcosms and 3rd gen $160 \mu \mathrm{M}$ microcosms were prepared using 2 nd gen microcosms sampled on day 117 as inocula $(10 \% \mathrm{v} / \mathrm{v})$. Conditions applied were identical to the 2nd gen microcosms, but two sets of higher concentrations of the pesticides were used, $40 \mu \mathrm{M}$ and $160 \mu \mathrm{M}$ for 2,4 D, MCPP, BAM and chloridazon, respectively. Abiotic controls and biotic control were prepared as above. Microcosms were incubated in the dark at $30{ }^{\circ} \mathrm{C}$, shaking at $150 \mathrm{rpm}$ for 185 days. Medium was refreshed and the cultures were re-spiked with 2,4-D to maintain the 2,4-D concentration on day 157, and acetate $(10 \mathrm{mM})$ and lactate $(10 \mathrm{mM})$ were re-spiked on days $21,34,47,57,63,81,85,91,99,112,125$ and 137. $1^{\text {st }}$ generation

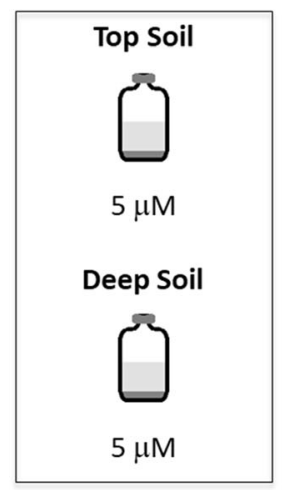

$2^{\text {nd }}$ generation $(5 \mu \mathrm{M})$

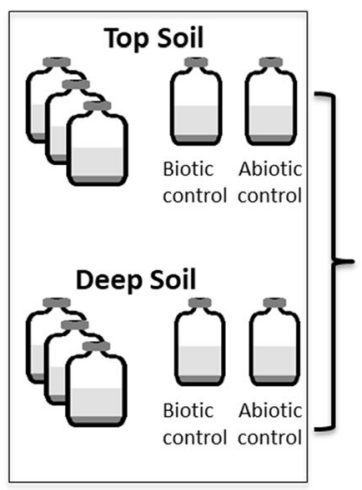

Day 94 Refresh media

Re-spike 2,4-D

Day 117 Sampling

Day 151 Re-spike 2,4-D

Day 206 Sampling $3^{\text {rd }}$ generation

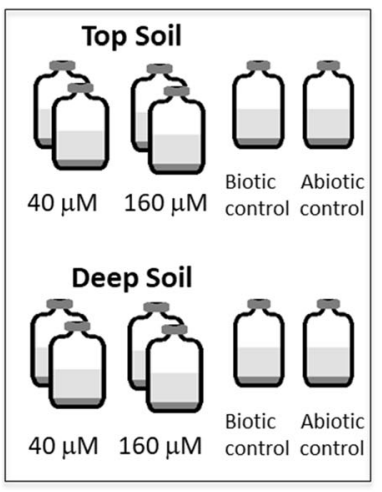

Day 99 Sampling

Day 135 Sampling

Day 157 Refresh media

Re-spike 2,4-D

Day 185 Sampling

Fig. 2 Schematic representation of the experimental set-up 
Chemical analyses

Liquid samples were collected regularly from microcosms with pesticides and immediately centrifuged at $10,000 \mathrm{~g}$ for $10 \mathrm{~min}$. Following centrifugation, the supernatant was transferred to an Eppendorf tube and stored at $-20{ }^{\circ} \mathrm{C}$ until analysis. The chlorinated pesticides 2,4-D, MCPP, BAM, chloridazon and the metabolic intermediates of 2,4-D transformation, 2,4DCP, 2-CP, 4-CP, and phenol were analysed on a Dionex UltiMate 3000 RS' HPLC-UV system (Thermo Fisher Scientific) installed with an Acquity UPLC CSH Phenyl-Hexyl $1.7 \mu \mathrm{m}$ column $(2.1 \times 150 \mathrm{~mm}$; Waters $)$. Injections of $50 \mu \mathrm{L}$ were performed by an auto-sampler, column temperature was set to $35^{\circ} \mathrm{C}$, and the flow was set to $0.3 \mathrm{~mL} \mathrm{~min}^{-1}$. To elute the pesticides, a binary gradient elution process was used with the following three stages: (1) 2 min with $75 \%$ solvent A $(0.1 \%$ formic acid in water) and $25 \%$ solvent $\mathrm{B}(0.1 \%$ formic acid in acetonitrile); (2) 7 min with $45 \%$ solvent $A$ and $55 \%$ solvent B; (3) 2 min with $75 \%$ solvent A and $25 \%$ solvent B. Transition between stages lasted $0.5 \mathrm{~min}$. Data was analyzed with Xcalibur software (Thermo Fisher Scientific), and a detection limit of $0.02 \mathrm{mg} / \mathrm{L}$ was used for all compounds. Methane was measured with HP 5890 gas chromatography according to Steinbusch et al. (2008). First order 2,4-D degradation rate constants were calculated according to Yang et al. (2017).

\section{DNA extraction}

Slurry samples ( $2 \mathrm{~mL}$ ) were taken at day 117 and 206 from all 2nd gen microcosms, and at day 135 and 185 from all 3rd gen microcosms, and stored at $-20{ }^{\circ} \mathrm{C}$ until DNA extraction. DNA extraction was performed using a PowerSoil DNA isolation Kit (MO-BIO, USA) according to the manufacturer's instruction. The quality and quantity of DNA was checked using a DS-11 FX Spectrophotometer/Fluorometer (DeNovix) and agarose gel electrophoresis.

\section{Quantitative PCR}

16S rRNA gene copy number of Dehalococcoides, Geobacter, Dehalobacter, Sulfurospirillum and Desulfitobacterium, as well as total Archaea and total bacteria were quantitated using a C1000 Touch $^{\mathrm{TM}}$
Thermal Cycler with a CFX384 Touch Real-Time PCR Detection System (Bio-Rad). The primers and qPCR program used are listed in Suplementary Table S1. Each reaction (final volume $10 \mu \mathrm{L}$ ) contained $5 \mu \mathrm{L}$ iQTM SYBR Green supermix (Bio$\mathrm{Rad}), 0.2 \mu \mathrm{L}$ of $10 \mu \mathrm{M}$ each primer, $2.6 \mu \mathrm{L}$ nuclease free water (Promega) and $2 \mu \mathrm{L}$ extracted DNA (diluted to $10 \mathrm{ng} \mu \mathrm{L}^{-1}$ ). Each reaction was run in triplicate and 3 non-template controls were included per experiment. The results were reported as the average of triplicate 16S rRNA gene copies per $\mathrm{mL}$ microcosms culture \pm standard deviation. The quantification of $\mathrm{De}$ halococcoides, Geobacter, Dehalobacter, Sulfurospirillum and Desulfitobacterium on the last day of the experiment, were statistically compared among the different 2,4 -D concentrations (2nd gen $5 \mu \mathrm{M}$ microcosms; 3rd gen $40 \mu \mathrm{M}$ microcosms and 3rd gen $160 \mu \mathrm{M}$ microcosms, and biotic control without 2,4-D) and in different soil horizons by ANOVA and Test Tukey-Krument (Discroll 1996).

Barcoded 16S rRNA amplicon synthesis and sequencing

A two-step PCR approach was used to generate barcoded amplicons of the V4 region of prokaryotic $16 \mathrm{~S}$ rRNA genes. In the first step, universally tagged (Tian et al. 2016) UniTag1-515F forward primer $\left(5^{\prime}\right.$ GAGCCGTAAGCCAGTCTGC - GTGYCAGCMGCCGCGGTAA $3^{\prime}$ ) and UniTag2-806RB reverse primer (5' GCCGTGACCGTGACATCG GGACTACNVGGGTWTCTAAT $3^{\prime}$ ) were used (EMP, 2016). Each reaction (final volume $50 \mu \mathrm{L}$ ) contained $10 \mu \mathrm{L} 5 \times \mathrm{HF}$ buffer (Thermo Fisher Scientific), $2.5 \mu \mathrm{L}$ of forward and reverse primer (each $0.5 \mu \mathrm{M}$ ), $1 \mu \mathrm{L}$ of $10 \mathrm{mM}$ dNTPs (Promega), 0.5 $\mu \mathrm{L}$ of $2 \mathrm{U} \mu \mathrm{L}^{-1}$ Phusion Hot Start II DNA polymerase (Thermo Fisher Scientific), $32.5 \mu \mathrm{L}$ nuclease-free water (Promega) and $1 \mu \mathrm{L}$ DNA, diluted to $10-20 \mathrm{ng}$ $\mu \mathrm{L}^{-1}$. PCR was conducted using the following settings: $98^{\circ} \mathrm{C}$ for $30 \mathrm{~s}$ followed by 25 cycles of $98^{\circ} \mathrm{C}$ for $10 \mathrm{~s}, 50{ }^{\circ} \mathrm{C}$ for $20 \mathrm{~s}$ and $72{ }^{\circ} \mathrm{C}$ for $20 \mathrm{~s}$ with a final extension at $72{ }^{\circ} \mathrm{C}$ for $10 \mathrm{~min}$. Five $\mu \mathrm{L}$ of PCR products were then electrophorized on a $1 \%(\mathrm{w} / \mathrm{v})$ agarose gel $(30 \mathrm{~min}$ at $100 \mathrm{~V})$ containing $1 \times$ SYBR Safe (Invitrogen) to confirm the fragment lengths ( $\sim 300 \mathrm{bp}$ ). Primers targeting the universal tags were used in the second step to generate uniquely barcoded 16S rRNA amplicons. The barcodes can be found in 
the supplementary information (Table S2). Each reaction of the second PCR (final volume $100 \mu \mathrm{L}$ ) contained: $20 \mu \mathrm{L}$ of $5 \times$ HF buffer (Thermo Fisher Scientific), $5 \mu \mathrm{L}$ barcoded forward and reverse primers (each $0.5 \mu \mathrm{M}$ ), $2 \mu \mathrm{L}$ of $10 \mathrm{mM}$ dNTPs, $1 \mu \mathrm{L}$ of $2 \mathrm{U}$ $\mu \mathrm{L}^{-1}$ Phusion Hot Start II DNA polymerase (Thermo Fisher Scientific), $62 \mu \mathrm{L}$ of nuclease-free water (Promega) and $5 \mu \mathrm{L}$ PCR product from the first step PCR. PCR was conducted using the following settings: $98{ }^{\circ} \mathrm{C}$ for $30 \mathrm{~s}$, followed by 5 cycles of $98^{\circ} \mathrm{C}$ for $10 \mathrm{~s}, 52{ }^{\circ} \mathrm{C}$ for $20 \mathrm{~s}$ and $72{ }^{\circ} \mathrm{C}$ for $20 \mathrm{~s}$ with a final extension at $72{ }^{\circ} \mathrm{C}$ for $10 \mathrm{~min}$. Five $\mu \mathrm{L}$ of PCR products were electrophorized on $1 \%(\mathrm{w} / \mathrm{v})$ agarose gel to check fragment lengths. Second step PCR products were purified using the Highprep ${ }^{\mathrm{TM}}$ PCR kit (Magbio) according to manufacturer's instructions, and the DNA concentrations were quantified using Qubit $^{\mathrm{TM}}$ dsDNA BR Assay kit (Invitrogen) and a DS11 FX Spectrophotometer/Fluorometer (DeNovix). Two hundred ng of DNA from each sample were pooled into a sequencing library, the resulting pool was purified and DNA concentrations quantified as before. The library was then sent to GATC Biotech (Germany) for Illumina MiSeq sequencing. Sequencing data were submitted to the European Bioinformatics Institute (EBI) under study accession number PRJEB37758.

MiSeq sequencing data processing and analysis

Sequence analysis of the raw data was performed in NG-Tax 2.0 using default settings (Poncheewin et al. 2020). Amplicon sequence variant (ASV) picking was done for each sample; sequences were ordered by abundance and a sequence was considered valid when its cumulative abundance was $\geq 0.1 \%$. Taxonomy was assigned using the SILVA reference database version 128 (Quast et al. 2013). Analyses of microbial communities were performed in $\mathrm{R}$ version 3.5 ( $\mathrm{R}$ Core Team 2014). Beta-diversity (between sample diversity) was calculated using weighted and unweighted UniFrac with the phyloseq package (Mcmurdie and Holmes 2013).

\section{Results}

Biodegradation of 2,4-D

2,4-D transforming microbial enrichments under methanogenic conditions were developed with soil samples from the Amazon (Rondônia, Brazil). In general, 2,4-D depletion was observed in all microcosms, and top soil showed a faster depletion than deep soil (Fig. 3) Limited decrease of 2,4-D was observed in abiotic controls (Fig. 3). Methane production was observed in all microcosms throughout the experiment (Supplementary Figure S1), confirming that the observed 2,4-D transformation occurred under methanogenic conditions. Methane was not detected in abiotic controls.

The 2 nd gen $5 \mu \mathrm{M}$ microcosms with top soil were used to calculate transformation kinetics over a 206-day incubation period with $5 \mu \mathrm{M} 2$,4-D. The rate constant (k) of 2,4-D depletion increased from 0.006 $\mathrm{d}^{-1}$ following the first spike (day 0 to 90 ) to $0.042 \mathrm{~d}^{-1}$ following the second spike (day 99 to 149) and third spike (day 156 to 206). One of the degradation products, $4 \mathrm{CP}(4.26 \mu \mathrm{M})$, was measured at the end of the experiments in the microcosms containing top soil. Phenol $(3.35 \mu \mathrm{M})$ was measured at day 199 and not detected anymore at the end of the incubation at day 206 (Fig. 3). The microcosms with deep soil showed a 2,4-D depletion rate constant of $0.017 \mathrm{~d}^{-1}$, with a limited decrease to $0.003 \mathrm{~d}^{-1}$ after the second spike at day 99. From day 99 to 206, 4CP was detected and reached a final concentration of $0.66 \mu \mathrm{M}$ (Fig. 3).

The initial rate constant in the $3 \mathrm{rd}$ gen $40 \mu \mathrm{M}$ top soil microcosms was $0.0027 \mathrm{~d}^{-1}$ (day 0 to 157 ) and decreased to $0.0021 \mathrm{~d}^{-1}$ (day 158-185) after the growth medium was refreshed. In the 3 rd gen $160 \mu \mathrm{M}$ top soil microcosms, the initial rate constant was $0.0014 \mathrm{~d}^{-1}$ (day 0 to 157 ), and $0.0021 \mathrm{~d}^{-1}$ after refreshing of the media. The microcosms with deep soil showed lower 2,4-D depletion rates of 0.0012 and $0.0010 \mathrm{~d}^{-1}$ in $3 \mathrm{rd}$ gen $40 \mu \mathrm{M}$ and $3 \mathrm{rd}$ gen $160 \mu \mathrm{M}$ microcosms, respectively (day 0 to 157 ).

Only the metabolite 4-CP was detected and quantified in the $3 \mathrm{rd}$ gen $40 \mu \mathrm{M}$ microcosms. No additional metabolites were detected in all other 3rd gen $40 \mu \mathrm{M}$ and 3rd gen $160 \mu \mathrm{M}$ microcosms. 2,4-DCP was also detected in the 2nd gen $5 \mu \mathrm{M}$, 3rd gen $40 \mu \mathrm{M}$ and $3 \mathrm{rd}$ gen $160 \mu \mathrm{M}$ microcosms, but could not be quantified due to peaks overlapping with an unknown compound 


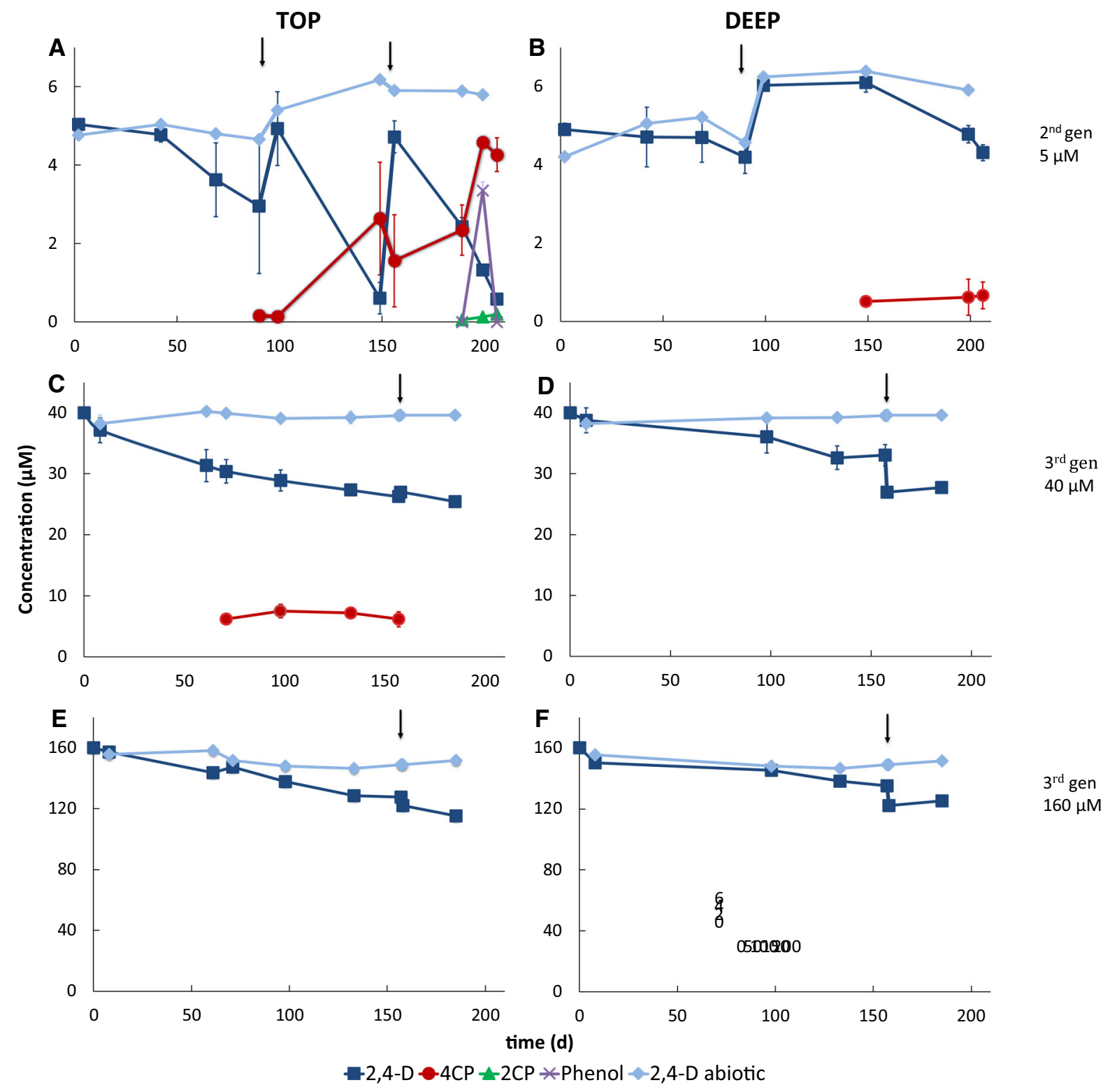

Fig. 3 2,4-D and its transformation metabolites during the enrichment process. a, b cultures amended with $5 \mu \mathrm{M} 2,4-\mathrm{D}$ (2nd generation); c, d cultures amended with $40 \mu \mathrm{M}$ 2,4-D (3rd generation); E-F: cultures amended with $160 \mu \mathrm{M}$ 2,4-D (3rd generation). Error bars represent the standard deviation of

in the LC-MS analyses. Removal of MCPP, BAM or chloridazon was not observed in any of the 2 nd or $3 \mathrm{rd}$ generation microcosms, and this data will not be discussed further. analysis from replicate bottles $(\mathrm{n}=3$ for $5 \mu \mathrm{M}$ cultures and $\mathrm{n}=2$ for 40 and $160 \mu \mathrm{M}$ cultures). Arrows indicate when 2,4-D was re-spiked. 2,4- $D, 2$,4-dichlorophenoxyacetic acid, 4-C 4-chlorophenoxyacetic acid, 4-CP 4-chlorophenol, 2-CP 2-chlorophenol. Image produced on Chemsketch (ACD)

Abundance of total bacteria, archaea and OHRB

The 16S rRNA gene copies of total bacteria and archaea per $\mathrm{mL}$ culture indicated that the community size remained relatively stable, within one order of magnitude in both top and deep soil microcosms (Fig. 4 and Supplementary Tables S2). The 16S rRNA 
TOP
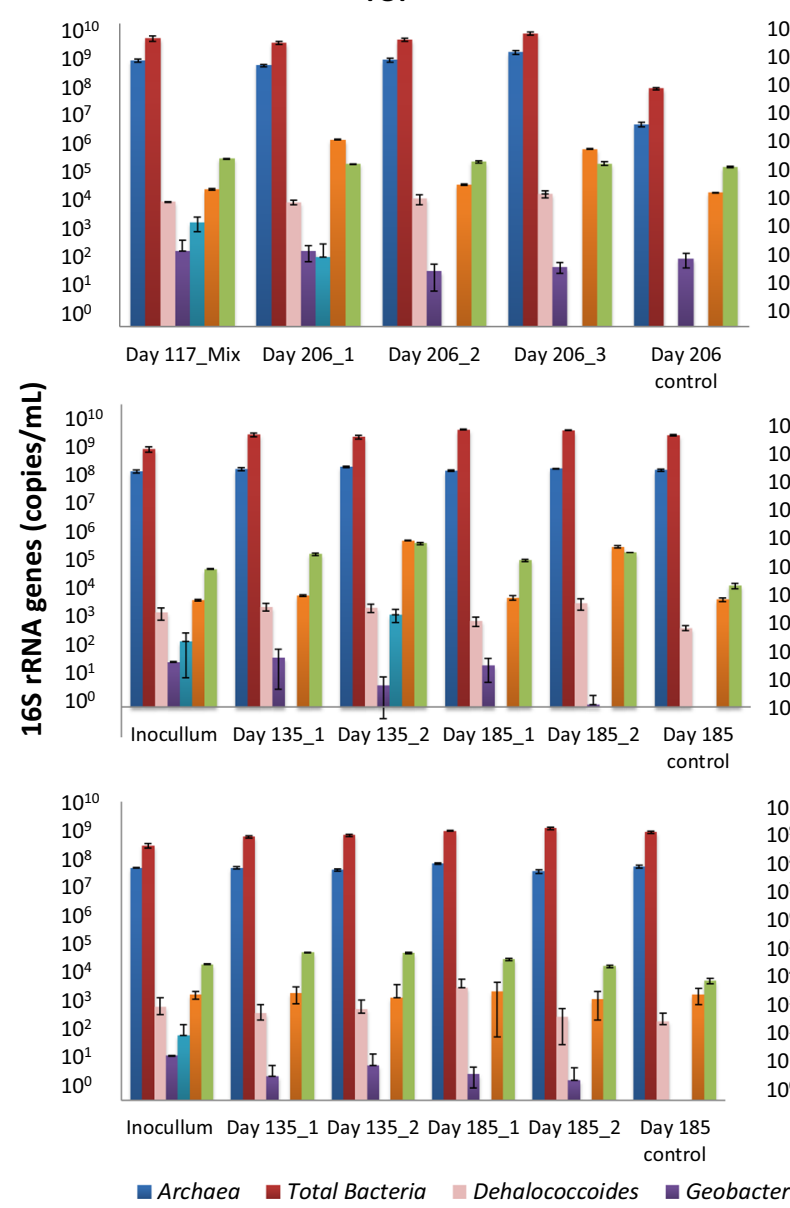

Fig. 4 16S rRNA gene abundance of total bacteria, archaea and different OHRB during the microcosm experiments. Each qPCR value and error bar represents the average and standard

gene copies of known OHRB such as Dehalococcoides, Sulfurospirillum and Desulfitobacterium were $10^{4}-10^{5}$ copies/ml top soil culture in the last day of incubation in $5 \mu \mathrm{M}$ 2,4-D. In higher concentration (40 and $160 \mu \mathrm{M} 2,4-\mathrm{D})$, the 16S rRNA gene copies was $10^{3}-10^{4} / \mathrm{ml}$ culture (Fig. 4 and Supplementary Table S2A). In deep soil enrichments, the 16S rRNA gene copies of Dehalococcoides, Sulfurospirillum and Desulfitobacterium were $10^{4}$ copies $/ \mathrm{ml}$ culture in the last day of incubation in $5 \mu \mathrm{M} 2,4-\mathrm{D}$ and $10^{3}-10^{2}$ copies/ml culture in 3rd gen (Suplementary S2B). Dehalobacter was only present at $10^{3} 16 \mathrm{~S}$ rRNA gene copies/ml culture in the last day of incubation in deep soil (5 $\mu \mathrm{M}$ 2,4-D). Geobacter was not considerably present at the end of the incubations (concentration below $10^{3}$ gene copies $\mathrm{mL}^{-1}$ ). Dehalococcoides was
DEEP
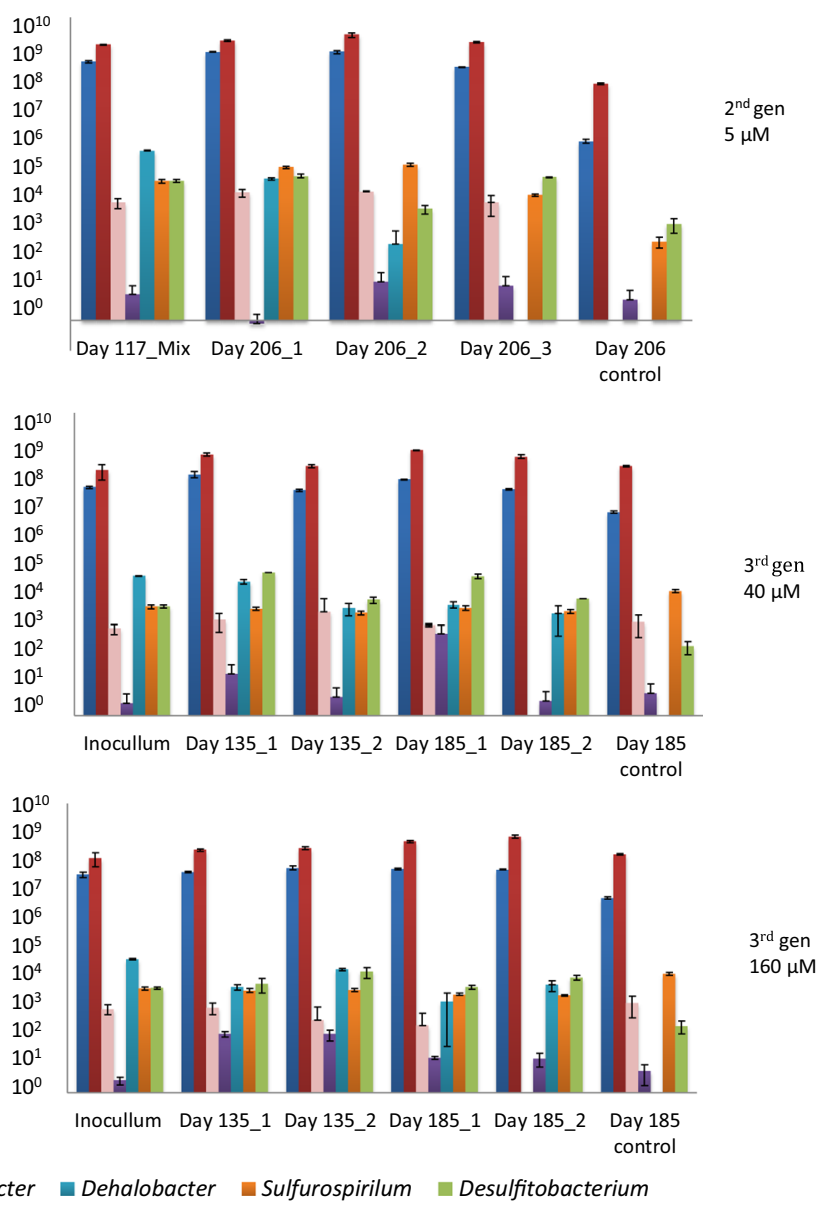

deviation of triplicate reactions. $5 \mu \mathrm{M} 2,4-\mathrm{D}$ is data from 2 nd generation, 40 and $160 \mu \mathrm{M}$ are 3rd generation microcosms

not detected in the controls (without pesticides), whereas Sulfurospirillum and Desulfitobacterium were present in top soil enrichments at $10^{5}$ gene copies/ml microcosm.

Statistical analysis using ANOVA showed that only Dehalococcoides abundance was significantly different between the different microcosms (biotic control without 2,4-D, 2nd gen $5 \mu \mathrm{M}$, 3rd gen $40 \mu \mathrm{M}$ and 3rd gen $160 \mu \mathrm{M}$ microcosms) with $\mathrm{p}$ value $=0.0004$. The Tukey Test pointed out that this difference occurred between the sample of 2 nd gen $5 \mu \mathrm{M}$ microcosms and biotic control and between 2nd gen $5 \mu \mathrm{M}$ and 3rd gen $160 \mu \mathrm{M}$ microcosms with $\mathrm{p}$ value $=0.05$ and 0.02 , respectively. 
Microbial community dynamics

In the 2nd gen microcosms $(5 \mu \mathrm{M})$, the relative abundance of some groups changed with time for both top and deep soil microcosms, although with limited variation within the microbial composition (Fig. 5).

Clostridium was one of the most predominant groups among all the microcosms. $C$. sensu stricto 7 was predominant in the 2 nd gen $5 \mu \mathrm{M}$ microcosms, representing in terms of relative abundance up to $20 \%$ of the top soil and $24 \%$ of the deep soil microcosms on day 117 . After 206 days, it represented around $8-20 \%$ of all sequences in the top soil and $26 \%$ in the deep soil. The relative abundance of Clostridium sensu stricto 12 in the $3 \mathrm{rd}$ gen $40 \mu \mathrm{M}$ microcosms increased at day 135 for top soil, and at day 185 for deep soil. In the $3 \mathrm{rd}$ gen $160 \mu \mathrm{M}$ top soil microcosms, the relative abundance of Clostridium sensu stricto 12 was $38 \%$ for one of the replicates at day 135, while the other replicate only showed around 7\%. At day 185 , between 50 to $70 \%$ of the microbial community belonged to that group. In the deep soil, for both 3rd gen $40 \mu \mathrm{M}$ and 3rd gen $160 \mu \mathrm{M}$ microcosms, the increase in relative abundance of Clostridium sensu stricto 12 became evident at day 185 , where the relative abundance amounted to around $20 \%$ for both replicates.

The microbial communities in the 2 nd gen $5 \mu \mathrm{M}$ microcosms for top and deep soil shared most of the predominant genera at day 117 , and only differed by the presence of two microbial groups. In the top soil, Cryptanaerobacter and Sedimentibacter were present, while these two groups were not part of the most abundant genera in the deep soil. Furthermore, Cryptanaerobacter was no longer an abundant genus in the top soil 3rd gen $40 \mu \mathrm{M}$ and 3rd gen $160 \mu \mathrm{M}$ microcosms. The microbial composition from top and deep soil 2nd generation $(5 \mu \mathrm{M})$ were more similar, in contrast to the $3 \mathrm{rd}$ gen $40 \mu \mathrm{M}$ and $3 \mathrm{rd}$ gen $160 \mu \mathrm{M}$
Top Soil
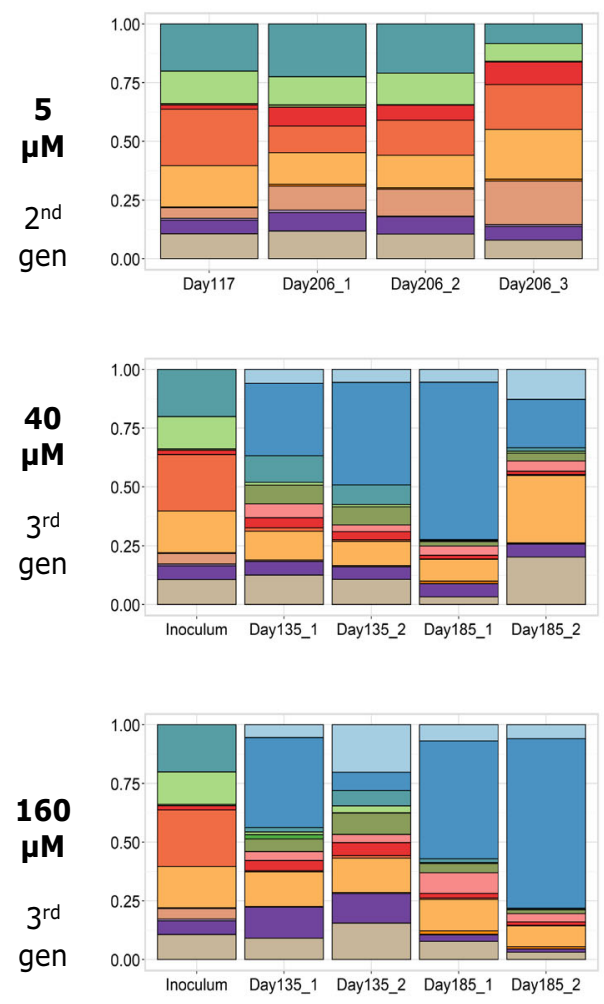

\section{Deep Soil}
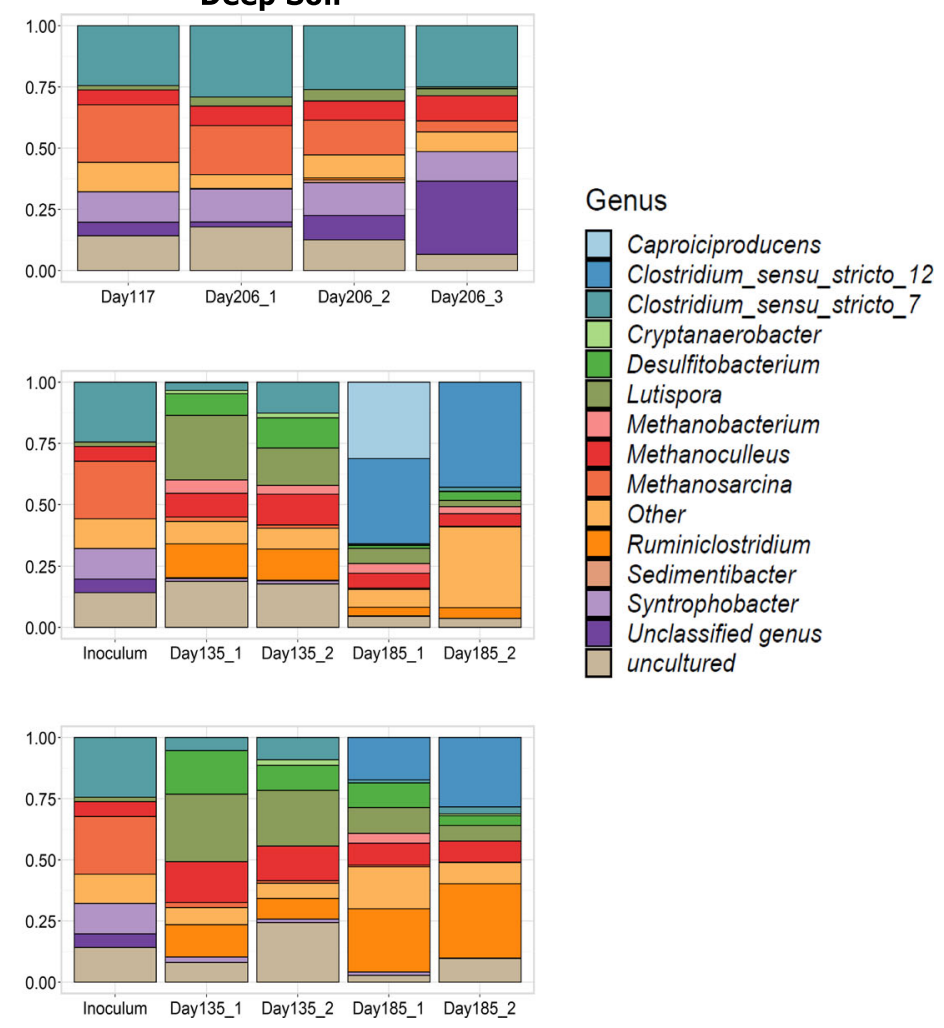

Fig. 5 Relative abundance of the 15 most abundant genera in top and deep soil cultures at different 2,4-D concentrations. Other - represents the cumulative relative abundance of genera that is not part of the top 15. Inoculum for 3rd generation is the $5 \mu \mathrm{M}$ microcosm from the 2 nd generation, at day 117 
microcosms. Principal coordinate analysis (PCoA) revealed influence of 2,4-D concentration and soil origin on microbial communities (Fig. 6). The 2nd gen $5 \mu \mathrm{M}$ microcosms, top and deep soil clustered with together, whereas the top 3rd gen $40 \mu \mathrm{M}$ and $3 \mathrm{rd}$ gen $160 \mu \mathrm{M}$ microcosms clusters were separated from the deep 3rd gen $40 \mu \mathrm{M}$ and 3rd gen $160 \mu \mathrm{M}$ microcosms (Fig. 6). Unfortunately, we cannot rule out the possibility that differences observed between 2 nd gen $5 \mu \mathrm{M}$ and 3rd gen $40 \mu \mathrm{M}$ and 3rd gen $160 \mu \mathrm{M}$ microcosms in terms of microbial composition are in part caused by the transfer, rather than the higher pesticide concentrations. Nevertheless, the lack of significant changes in microbial community over time during incubation of 2 nd gen $5 \mu \mathrm{M}$ microcosms that are in contrast to the significant changes in time in $3 \mathrm{rd}$ gen $40 \mu \mathrm{M}$ and $3 \mathrm{rd}$ gen $160 \mu \mathrm{M}$ microcosms, points towards a selective role of the pesticides.

\section{Discussion}

Degradation of 2,4-D

Our results show that 2,4-D can be degraded with material from an Amazonian agricultural soil that has received 2,4-D in the past to control broadleaf weeds on a pasture. The anaerobic biotransformation rate of 2,4-D was faster with top soil as inoculum than with deep soil, independent of the applied concentration of

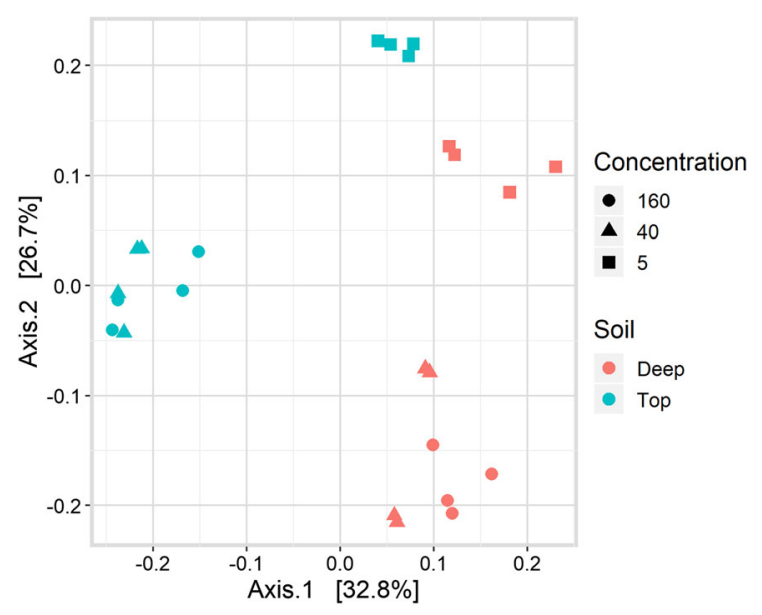

Fig. 6 Principal coordinate analysis (PCoA) of microbial communities (ASVs) in top and deep soil based on unweighted unifrac distances
2,4-D (Fig. 3). The majority of 2,4-D degradation studies focused on aerobic processes, with intermediates being detected and involved enzymes identified (Don and Pamberton 1981; Fukumore and Hausinger 1993; Furthorpe et al. 1995; Valey et al. 1996). Much less is known about anaerobic 2,4-D biotransformation and involved pathways. Some studies correlated 2,4-D anaerobic biotransformation with reductive dechlorination (Boyle et al. 1999; Wang et al. 2009), whereas others added carbon sources such as acetate, glucose, propionate, butyrate, and sucrose (Boyle et al.1999; Roubles-Gonzales et al. 2006; Wang et al. 2009; Yang et al. 2018; Luo et al. 2019). In our study, we used Brazilian soil as inoculum to study 2,4-D biotransformation. We found only one other study, related to Amazon samples and 2.4-D. However, this group studied the resistance of aerobic microorganisms to $905 \mu \mathrm{M}$ of $2,4-\mathrm{D}$, but not its degradation (Mussy et al. 1999).

The 2,4-D depletion rates decreased in our 3rd gen $40 \mu \mathrm{M}$ and 3 rd gen $160 \mu \mathrm{M} 3 \mathrm{rd}$ microcosms. Two factors can be associated with this. Possibly, crucial growth compounds in the soil were reduced upon transferring from one generation to the other, and during refreshing of the medium, resulting in a reduced degradation rate. Wang and He (2013) have reported the importance of sediments or sediment substitutes during the enrichment of polychlorinated biphenyl dechlorinating cultures. In addition, soils are a source of humic acids, that have been shown to facilitate the reductive dechlorination of 2,4-D (Wang et al. 2009). A second possible explanation is toxicity effects of 2,4-D at higher concentrations. Organohalogens are known to inhibit methanogenesis at higher concentrations. While Wu et al. (2009) demonstrated that a pure culture of $C$. koreensis CY01 was capable of degrading 2,4-D at concentrations up to $180 \mu \mathrm{M}$, $20 \mu \mathrm{M}$ greater than the concentrations used here, that study did not fully explore toxicity effects on transformation rates. As our results seem to suggest that toxicity of 2,4-D could affect transformation, we suggest future work to identify 2,4-D toxicity thresholds.

In the top soil microcosms, 2-CP and phenol were detected, which are known intermediates of 2,4-D reductive dechlorination (Gibson and Suflita, 1986; Bryant et al. 1992; Roblez-Gonzalez et al. 2006; Yang et al. 2017) (Fig. 3). Moreover, 4-CP was produced but not degraded further in 2 nd gen $5 \mu \mathrm{M}$ and 3 rd gen 
$40 \mu \mathrm{M}$ microcosms, indicating $4-\mathrm{CP}$ as a terminal product of 2,4-D biotransformation that was also observed in some of the deep soil cultures, over the time frame monitored during this study. Other studies have similarly reported 4-CP as a final product of 2,4D biotransformation (Boyle et al. 1999; Zipper et al. 1999; Roblez-Gonzalez et al. 2006). In 3rd gen $160 \mu \mathrm{M}$ microcosms, only 2,4-DCP was detected (not quantified), suggesting an incomplete biotransformation of 2,4-D, possibly due to a toxic effect of the higher 2,4-D concentration.

Characterization of microbial communities involved in 2,4-D biodegradation

Microbial community composition seems to be affected by both the origin of the inoculum and the generations with different 2,4-D concentration (Fig. 6). For all the tested 2,4-D concentrations, top soil microbial communities transformed 2,4-D faster than deep soil communities. Regarding the different generation microcosms, the 2,4-D depletion rates were higher at 2nd gen $5 \mu \mathrm{M}$ microcosms than at higher 2,4$\mathrm{D}$ concentrations ( $3 \mathrm{rd}$ gen). In top soils at 2 nd gen $5 \mu \mathrm{M}$ microcosms, 2,4-D, we found two microbial groups that could be associated with 2,4-D biodegradation. One of these groups is Cryptanaerobacter, a microbial group with members capable of transforming phenol, a degradation product of 2,4-D, into benzoate (Juteau et al. 2005). We did note phenol depletion in some of our microcosms, but as we did not measure benzoate, we cannot confirm a similar phenol transformation. The second group that was present in top soil is Sedimentibacter, previously shown to support the growth of Dehalobacter in soil enrichments fed with acetate or lactate (Van Doesburg et al. 2005). Sedimentibacter was previously involved in the dehalogenation of $\beta$-hexachlorocyclohexane $(\beta$ $\mathrm{HCH}$ ), which is a organochlorine micropollutant, similar to 2,4-D (Van Doesburg et al. 2005). Metagenome analysis showed that Sedimentibacter in co-culture with Dehalobacter synthesized cobalamin (vitamin B12), an essential cofactor for reductive dehalogenases (Maphosa et al. 2012). We hypothesize that the contribution of Sedimentibacter in our top soil microcosms could be also cobalamin production.

In our study, qPCR assays showed no enrichment of Dehalococcoides, Sulfurospirillum or Desulfitobacterium during 2nd and 3rd generation assay.
Moreover, Dehalobacter and Geobacter strongly decreased in numbers, indicating that they were most likely not involved in 2,4-D transformation (Fig. 4 and Table S2 Supplementary). The presence of OHRB indicates that these microorganisms were present in the Amazon soil. However, our results indicate that these microorganisms were not further enriched during transfer from 2 nd gen to 3 rd gen microcosms.

The transformation of 2,4-D in our microcosms could likely be due to co-metabolism. Co-metabolic reductive dechlorination mediated by vitamin $\mathrm{B} 12$ has been demonstrated for other chlorinated compounds such as chloroform, tetrachloromethane, tetrachloroethene, among others (Gantzer and Wackett 1991, Workman et al. 1997, Smidt and de Vos 2004, Guereiro-Barajas and Field 2005; Becker and Freedman 2014, Peng et al. 2020). The genus Clostridium was one of the most dominant groups among all microcosms (Fig. 5), and Clostridium that has been identified before as one of the main genera involved in cometabolic transformation of 2,4-D (Yang et al. 2018). Furthermore, members of the genus Clostridium are also known for their potential for co-metabolic transformation of chlorinated compounds using enzymes involved in the Wood-Ljungdahl pathway (WLP) (Peng et al. 2020). Unfortunately, we did not monitor cobalamin, but as mentioned before, we observed 2,4-D transformation, and no enrichment of OHRB. This fact, combined with the presence of vitamin B12/cobalamin producing microorganisms in high abundance, could be evidence of that cometabolic dechlorination contributes or even dominates 2,4-D biotransformation observed in this work.

\section{Conclusions}

To the best of our knowledge, this study is the first report of microbial communities in Brazilian soil samples involved in anaerobic 2,4-D transformation, with samples from the Amazon forest. 2,4-D transformation was observed and its depletion rate decreased slightly in the 3rd generation, indicating no enrichment occurred from the 2 nd to the 3 rd generation. This could have been caused by the increase in concentration of 2,4-D from $5 \mu \mathrm{M}$ to 40 or $160 \mu \mathrm{M}$, and/or that simply more time was needed in the 3rd generation incubations to activity to be re- 
established. Chlorinated phenols and phenol were detected as intermediates.

qPCR showed no notable enrichment of OHRB Dehalococcoides, Sulfurospirillum and Desulfitobacterium. 16S rRNA gene sequencing indicated that the genus Clostridium was one of the most dominant groups among all microcosms that are known for their potential for co-metabolic organochlorine transformation. Differences in microbial community composition between the various microcosms could be explained by the origin of the inoculum and the 2,4-D concentration.

To conclude, the top soil microcosms showed a better 2,4-D degradation than the deep soil microcosms. Our results are a first step towards understanding the fate of 2,4-D in Amazon soil and contribute to the development of bioremediation strategies in South American forests.

Acknowledgement This study was financed in part by the Coordenação de Aperfeiçoamento de Pessoal de Nível Superior-Brasil (CAPES)_Finance Code 001 and a Research fellowship grant from the Wageningen Institute for Environment and Climate Research (WIMEK), the Netherlands.

Open Access This article is licensed under a Creative Commons Attribution 4.0 International License, which permits use, sharing, adaptation, distribution and reproduction in any medium or format, as long as you give appropriate credit to the original author(s) and the source, provide a link to the Creative Commons licence, and indicate if changes were made. The images or other third party material in this article are included in the article's Creative Commons licence, unless indicated otherwise in a credit line to the material. If material is not included in the article's Creative Commons licence and your intended use is not permitted by statutory regulation or exceeds the permitted use, you will need to obtain permission directly from the copyright holder. To view a copy of this licence, visit http://creativecommons.org/licenses/by/4.0/.

\section{References}

Adrian L, Hansen SK, Fung JM, Görisch H, Zinder SH (2007) Growth of Dehalococcoides strains with chlorophenols as electron acceptors. Environ Sci Technol 41(7):2318-2323

Albuquerque AF, Ribeiro JS, Kummrow F, Nogueira AJA, Montagner CC, Umbuzeiro GA (2016) Pesticides in Brazilian freshwaters: a critical review. Environ Sci Process Impacts 18(7):779-787

Amos BK, Sung Y, Fletcher KE, Gentry TJ, Wu WM, Criddle CS, Löffler FE (2007) Detection and quantification of Geobacter lovleyi strain SZ: implications for bioremediation at tetrachloroethene-and uranium-impacted sites. Appl Environ Microbiol 73(21):6898-6904

ANVISA, Brazilian Sanitary Surveillance Agency (2016). Retrieved from: http://portal.anvisa.gov.br/documents/ 111215/117782/D27\%2B\%2B24D.pdf/8548d5b3-f30649df-ac49-4498bc5768d8

ANVISA, Brazilian Sanitary Surveillance Agency (2011). Agrotóxicos e Toxicologia, Legislação(Law no. 7.802/89). Retrieved from: http://portal.anvisa.gov.br/wps/portal/ anvisa/home/agrotoxicotoxicologia/

Atashgahi S, Lu Y, Smidt H (2016) Overview of known organohalide-respiring bacteria-phylogenetic diversity and environmental distribution. In: Adrian L, Löffler F (eds) Organohalide-Respiring Bacteria. Springer, Berlin Heidelberg, pp 63-105

Azubuike CC, Chikere CB, Okpokwasili GC (2016) Bioremediation techniques-classification based on site of application: principles, advantages, limitations and prospects. World J Microbiol Biotechnol 32(11):180

Barbosa AM, de Solano M, Umbuzeiro LM (2015) Pesticides in drinking water, the Brazilian monitoring program. Front Public Health 3:246

Becker GJ, Freedman DL (1994) Use of cyanocobalamin to enhance anaerobic biodegradation of chloroform. Environ Sci Technol 28(11):1942-1949

Berestovskaya YY, Ignatov VV, Markina LN, Kamenev AA, Makarov OE (2000) Degradation of ortho-chlorophenol, para-chlorophenol, and 2, 4-dichlorophenoxyacetic acid by the bacterial community of anaerobic sludge. Microbiology 69(4):397-400

Boyle AW, Knight VK, Häggblom MM, Young LY (1999) Transformation of 2, 4-dichlorophenoxyacetic acid in four different marine and estuarine sediments: Effects of sulfate, hydrogen and acetate on dehalogenation and sidechain cleavage. FEMS Microbiol Ecol 29(1):105-113

Bray JR, Curtis JT (1957) An ordination of the upland forest communities of southern Wisconsin. Ecol Monogr 27(4):325-349

Collins G, Foy C, McHugh S, O'Flaherty V (2005) Anaerobic treatment of 2, 4, 6-trichlorophenol in an expanded granular sludge bed-anaerobic filter (EGSB-AF) bioreactor at 15 C. FEMS Microbiol Ecol 53(1):167-178

de Morais JFL, Volkof B, Cerri CC, Bernoux M (1996) Soil properties under Amazon forest and changes due to pasture installation of Rondônia. Brazil Geoderma 70(1):66-81

Dean JA (1979) Lange's Handbook of Chemistry, 12th edn. McGraw Hill Book Company, New York

Dolfing J, Novak I (2015) The Gibbs free energy of formation of halogenated benzenes, benzoates and phenols and their potential role as electron acceptors in anaerobic environments. Biodegradation 26(1):15-27

Don RH, Pamberton JM (1981) Properties of six pesticides degradation plasmids isolated from Alcaligenes eutrophus. J Bacterial 145:681-686

Driscoll WC (1996) Robustness of the ANOVA and TukeyKramer statistical tests. Comput Ind Engineering 31(1):265-268

Duhamel M, Edwards EA (2006) Microbial composition of chlorinated ethene-degrading cultures dominated by $D e$ halococcoides. FEMS Microbiol Ecol 58(3):538-549 
Earth Microbiome Project (EMP) (2016). 16S Illumina Amplicon Protocol. Retrieved from: http://press.igsb.anl.gov/ earthmicrobiome/protocols-and-standards/16s/

Environmental Protection Agency (EPA). (2005) Reregistration Eligibility Decision for 2,4-D. Retrieved from:https:// archive.epa.gov/pesticides/reregistration/web/pdf/24d_ red.pdf

Fukumori F, Hausinger RP (1993) Purification and characterization of 2,4-D dichlorophenoxyacetate/alpha-ketoglutarate dioxygenase. J Biol Chem 268:24311-24317

Fulthorpe R, McGowan C, HolbenTiedje MOJM (1995) 2,4-D degrading bacteria contain mosaics of catabolic gene. Appl Environ Microbiol 61:3274-3281

Futagami T, Furukawa K (2016) The Genus Desulfitobacterium. In: Adrian L, Löffler F (eds) Organohalide-Respiring Bacteria. Springer, Berlin Heidelberg, pp 173-207

Gantzer CJ, Wackett LP (1991) Reductive dechlorination catalysed by bacterial transition-metal coenzymes. Environ Sci Technol 25(4):715-722

Gibson SA, Suflita JM (1986) Extrapolation of biodegradation results to groundwater aquifers: reductive dehalogenation of aromatic compounds. Appl Environ Microbiol 52(4):681-688

Goris T, Diekert G (2016) The genus Sulfurospirillum. In: Adrian L, Löffler F (eds) Organohalide-Respiring Bacteria. Springer, Berlin Heidelberg, pp 209-234

Guerreiro-Barajas C, Field JA (2005) Riboflavin- and cobalamin-mediated biodegradation of chloroform in a methanogenic consortium. Biotechnol Bioeng 89(5):539-550

Ha DD (2018) Anaerobic degradation of 2,4-dichlorophenoxyacetic acid by Thauera sp. DKT Biodegradation 29:499-510

Holliger C, Hahn D, Harmsen H, Ludwig W, Schumacher W, Tindall B, Vazquez F, Weiss N, Zehnder AJB (1998) Dehalobacter restrictus gen. nov. and sp. nov., a strictly anaerobic bacterium that reductively dechlorinates tetraand trichloroethene in an anaerobic respiration. Arch Microbiol 169:313-321

Holliger C, Regeard C, Diekert G (2004) Dehalogenation by anaerobic bacteria. In: Häggblom MM, Bossert ID (eds) Dehalogenation. Springer, Boston, MA, pp 115-157

Hug LA, Maphosa F, Leys D, Löffler FE, Smidt H, Edwards EA, Adrian L (2013) Overview of organohalide-respiring bacteria and a proposal for a classification system for reductive dehalogenases. Philos Trans R Soc Lond B Biol Sci 368(1616):20120322

Jardim AN, Caldas ED (2012) Brazilian monitoring programs for pesticide residues in food - Results from 2001 to 2010. Food Control 25(2):607-616

Juteau P, Côté V, Duckett MF, Beaudet R, Lépine F, Villemur R, Bisaillon JG (2005) Cryptanaerobacter phenolicus gen. nov., sp. nov, an anaerobe that transforms phenol into benzoate via 4-hydroxybenzoate. Int J Syst Evol Microbiol 55(1):245-250

Karlsson A, Ejlertsson J, Nezirevic D, Svensson BH (1999) Degradation of phenol under meso- and thermophilic, anaerobic conditions. Anaerobe 5(1):25-35

Li Z, Suzuki D, Zhang C, Yoshida N, Yang S, Katayama A (2013) Involvement of Dehalobacter strains in the anaerobic dechlorination of 2, 4, 6-trichlorophenol. J Biosci Bioeng 116(5):602-609
Li ZL, Nan J, Yang JQ, Jin X, Katayama A, Wang AJ (2015) Temporal distributions of functional microbes and putative genes associated with halogenated phenol anaerobic dehalogenation and further mineralization. RSC Adv 5(108):89157-89163

Lu Y (2016) Ecophysiology and environmental distribution of organohalide-respiring bacteria (Doctoral dissertation), Wageningen University

Luo Y, Atashgahi S, Rijnaarts HHM, Cornars RNJ, Sutton NB (2019) Influence of different redox conditions and dissolved organic matter on pesticide biodegradation in simulated groundwater systems. Sci Total Environ 677:692-699

Madsen T, Licht D (1992) Isolation and characterization of an anaerobic chlorophenol-transforming bacterium. Appl Environ Microbiol 58(9):2874-2878

Magurran AE (2013) Ecological diversity and its measurement. Springer, Dordrecht

Maphosa F, van Passel MWJ, de Vos WM, Smidt H (2012) Metagenome analysis reveals yet unexplored reductive dechlorinating potential of Dehalobacter sp E1 growing in co-culture with Sedimentibacter sp. Environ Microbiol Rep 4(6):604-616

Mcmurdie PJ, Holmes S (2013) phyloseq: An R package for reproducible interactive analysis and graphics of microbiome census data. PLoS ONE 8(4):e61217

Mussy MH, Brucha G, Ris MG, Ushimaru PI, Yamashita M, Bastos WR (2013) Identification of microorganisms resistant to the herbicide 2,4-dichlorophenoxyacetic acid $(2,4-D)$ in soils of Rondonia, Brazil. Interciencia 38:353-357

Muyzer G, de Waal EC, Uitterlinden AG (1993) Profiling of complex microbial populations by denaturing gradient gel electrophoresis analysis of polymerase chain reactionamplified genes coding for $16 \mathrm{~S}$ rRNA. Appl Environ Microbiol 59(3):695-700

OECD/Food and Agriculture Organization of the United Nations (FAO) (2015) OECD-FAO Agricultural Outlook 2015, OECD Publishing, Paris. Doi: https://doi.org/10. 1787/agr_outlook-2015-en

Oksanen J, Blanchet FG, Friendly M, Kindt R, Legendre P, McGlinn D, Minchin PR, O'Hara RB, Simpson GL, Solymos P, Stevens MHH, Szoecs E, Wagner H (2017) vegan: Community Ecology Package. R package version 2.4-3. https://CRAN.R-project.org/package=vegan

Peng P, Lu Y, Bosma TNP, Nijenhuis I, Nijsse B, Shitty SA, Ruecker A, Umanents A, Ramiro-Garcia J, Kappler A, Sipkema D, Smidt H, Atashgahi S (2020) Metagenomicand cultivation-based of anaerobic chloroform biotransformation in hypersaline sediments as natural source of chloromethanes. Microorganisms 8(5):665

Pignati WA, Lima FANS, de Lara SS, Correa MLM, Barbosa JR, Leão LHC, Pignati MG (2017) Spatial distribution of pesticide use in Brasil; a strategy for health surveillance. Ciência e saúde coletiva 22(10):3281-3293

Poncheewin W, Hermes GDA, van Dam JCJ, Koehorst JJ, Smidt H, Schaap PJ (2020) NG-Tax 2.0: A semantic framework for high-throughput amplicon analysis. Front Genet 10:1-12

Quast C, Pruesse E, Yilmaz P, Gerken J, Schweer T, Yarza P, Peplies J, Glöckner FO (2013) The SILVA ribosomal RNA 
gene database project: Improved data processing and webbased tools. Nucleic Acids Res 41(D1):590-596

R Core Team (2014) R: A language and environment for statistical computing. R Foundation for Statistical Computing

Ramiro-Garcia J, Hermes GD, Giatsis C, Sipkema D, Zoetendal EG, Schaap PJ, Smidt H (2016) NG-Tax, a highly accurate and validated pipeline for analysis of $16 \mathrm{~S}$ rRNA amplicons from complex biomes. F1000Research 5:1791

Rebelo RM, Vasconcelos RA, Buys BDMC, Rezende JA, Moraes KOC, Oliveira RP (2010) Produtos agrotóxicos e afins comercializados em 2009 no Brasil: uma abordagem ambiental. Instituto Brasileiro do Meio Ambiente e dos Recursos Naturais Renováveis (IBAMA), Brasília, Brazil

Richardson RE (2016) Organohalide-respiring bacteria as members of microbial communities: Catabolic food webs and biochemical interactions. In: Adrian L, Löffler F (eds) Organohalide-Respiring Bacteria. Springer, Berlin Heidelberg, pp 309-341

Robles-González I, Rios-Leal E, Ferrera-Cerrato R, EsparzaGarcia F, Rinderkenecht-Seijas N, Poggi-Varaldo HM (2006) Bioremediation of a mineral soil with high contents of clay and organic matter contaminated with herbicide 2 , 4-dichlorophenoxyacetic acid using slurry bioreactors: effect of electron acceptor and supplementation with an organic carbon source. Process Biochem 41(9):1951-1960

Rodrigues JL, Pellizari VH, Mueller R, Baek K, Jesus EDC, Paula FS, Mirza B, Hamaoui GS Jr, Tsai SM, Feigl B, Tiedje JM, Bohannan BJM, Nüsslein K (2013) Conversion of the Amazon rainforest to agriculture results in biotic homogenization of soil bacterial communities. Proc Natl Acad Sci USA 110(3):988-993

Sandmann ERIC, Loos MA, Van Dyk LP (1988) The microbial degradation of 2, 4-dichlorophenoxyacetic acid in soil. In: Ware GW (ed) Reviews of Environmental Contamination and Toxicology, vol 101. Springer, New York, pp 1-53

Smidt H, de Vos WM (2004) Anaerobic microbial dehalogenation. Annu Rev Microbiol 58:43-73

Smits TH, Devenoges C, Szynalski K, Maillard J, Holliger C (2004) Development of a real-time PCR method for quantification of the three genera Dehalobacter, Dehalococcoides, and Desulfitobacterium in microbial communities. J Microbiol Methods 57(3):369-378

Steinbusch KJJ, Hamelers HVM, Buisman CJN (2008) Alcohol production through volatile fatty acids reduction with hydrogen as electron donor by mixed cultures. Water Res 42:4059-4066

Streber WR, Timmis KN, Zenk MH (1987) Analysis, cloning, and high-level expression of 2,4-dichlorophenoxyacetate mono- oxygenase gene tfdA of Alcaligenes eutrophus JMP134. J Bacteriol 169:2950-2955

Thibodeau J, Gauthier A, Duguay M, Villemur R, Lépine F, Juteau P, Beaudet R (2004) Purification, cloning, and sequencing of a 3, 5-dichlorophenol reductive dehalogenase from Desulfitobacterium frappieri PCP-1. Appl Environ Microbiol 70(8):4532-4537

Touzel JP, Albagnac G (1983) Isolation and characterization of Methanococcus mazei strain MC3. FEMS Microbiol Letters 16:241-245

Vallaeys T, Fulthorpe RR, Wright AM, Soulas G (1996) The metabolic pathway of 2,4 dichlorophenoxyacetic acid degradation involves different families of $t f d A$ and $t f d B$ genes according to PCR-RFLP analysis. FEMS Microbiol Ecol 20:63-172

Van Doesburg W, van Eekert MHA, Middeldorp PJM, Balk M, Schraa G, Stams AJM (2005) Reductive dechlorination of $\beta$-hexachlorocyclohexane $(\beta-\mathrm{HCH})$ by a Dehalobacter species in coculture with a Sedimentibacter sp. FEMS Microbiol Ecol 54(1):87-95

Wang S, He J (2013) Phylogenetically distinct bacteria involve extensive dechlorination of Aroclor 1260 in sediment-free cultures. PLoS ONE 8(3):59178

Wang YB, Wu CY, Wang XJ, Zhou SG (2009) The role of humic substances in the anaerobic reductive dechlorination of 2,4-dichlorophenoxyacetic acid by Comamonas koreensis strain CY01. J Hazard Mater 164(2-3):941-947

Wang S, Zhang W, Yang KL, He J (2014) Isolation and characterization of a novel Dehalobacter species strain TCP1 that reductively dechlorinates 2, 4, 6-trichlorophenol. Biodegradation 25(2):313-323

Workman DJ, Woods SL, Gordy YA, Fredrickson JK, Truex MJ (1997) Microbial reduction of vitamin $B_{12}$ by Shewanella alga Strain BrY with subsequent transformation of carbon tetrachloride. Environ Sci Technol 31(8):2292-2297

World Health Organization (WHO). (2000). Benzoic acid and sodium benzoate. Retrieved from: http://www.who.int/ ipcs/publications/cicad/cicad26_rev_1.pdf

Wu CY, Zhuang L, Zhou SG, Li FB, Li XM (2009) Fe (III)enhanced anaerobic transformation of 2, 4-dichlorophenoxyacetic acid by an iron-reducing bacterium Comamonas koreensis CY01. FEMS Microbiol Ecol 71(1):106-113

Yang Z, Xu X, Dai M, Wang L, Shi X, Guo R (2017) Rapid degradation of 2, 4-dichlorophenoxyacetic acid facilitated by acetate under methanogenic condition. Bioresour Technol 232:146-151

Yang Z, Shi X, Dai M, Wang L, Xu X, Guo R (2018) Promoting degradation of 2,4-dichlorophenoxyacetic acid with fermentative effluents from hydrogen-producing reactor. Chemosphere 201:859-863

Yu Y, Lee C, Kim J, Hwang S (2005) Group-specific primer and probe sets to detect methanogenic communities using quantitative real-time polymerase chain reaction. Biotechnol Bioeng 89(6):670-679

Yuzir A, Abdullah N, Chelliapan S, Sallis P (2013) Effect of mecoprop (RS)-MCPP on the biological treatment of synthetic wastewater in an anaerobic membrane bioreactor. Bioresour Technol 133:158-165

Zharikova NV, Iasakov TR, Zhurenko EY, Korobov VV, Markusheva TV (2018) Bacterial genes of 2,4Dichlorophenoxyacetic acid degradation encoding $\alpha$-ketoglutarate-dependent dioxygenase activity. Biol Bull Rev 8:155-167

Zinder SH, Cardwell SC, Anguish T, Lee M, Koch M (1984) Methanogenesis in a thermophilic $\left(58^{\circ} \mathrm{C}\right)$ anaerobic digestor: Methanothrix sp. as an important aceticlastic methanogen. Appl Environ Microbiol 47:796-807

Zipper C, Bolliger C, Fleischmann T, Suter MJF, Angst W, Müller MD, Kohler HPE (1999) Fate of the herbicides mecoprop, dichlorprop, and 2, 4-D in aerobic and anaerobic sewage sludge as determined by laboratory batch studies and enantiomer-specific analysis. Biodegradation 10(4):271-278 
Zopfi J, Ferdelman TG, Fossing H (2004) Distribution and fate of sulfur intermediates sulfite, tetrathionate, thiosulfate, and elemental sulfur in marine sediments. Geol Soc Am Spec Pap 379:97-116
Publisher's Note Springer Nature remains neutral with regard to jurisdictional claims in published maps and institutional affiliations. 